\title{
Antidiabetic and hypolipidemic potential of Rhazya stricta Decne extract and its fractions
}

\author{
*Asma Ahmed ${ }^{1}$, Muahammad Javaid Asad ${ }^{1}$, Muhammad Sheeraz Ahmad ${ }^{1}$, Rehmatullah Qureshi², Syed Imam Shah ${ }^{3}$, \\ Hina Gul ${ }^{4}$ and Muhammad Gulfraz ${ }^{1}$ \\ ${ }^{1}$ Department of biochemistry, Pir Mehr Ali Shah, Arid Agriculture University, Rawalpindi, Pakistan \\ 2 Department of Botany, Pir Mehr Ali Shah, Arid Agriculture University, Rawalpindi, Pakistan \\ ${ }^{3}$ National Veterinary Laboratories, PARK Road, Islamabad, Pakistan \\ ${ }^{4}$ Department of Plant Sciences, Faculty of Biological Sciences, Quaid-i-Azam University, Islamabad, Pakistan
}

\begin{abstract}
Diabetes mellitus is the most common human disease and there is growing interest for plant based therapy in managing diabetes mellitus specifically in the developing world. In the present study, Rhazya stricta Decne extract was analysed for its antidiabetic activities. Crude methanolic extracts of different plant parts were tested in vivo on albino mice Balb-C, for the reduction of blood glucose, urea, cholesterol, triacylglycerides and glycosylated haemoglobin. Results obtained showed that leaves of $R$. stricta have best antidiabetic effect by reducing blood glucose level, Glycosylated haemoglobin, triacylglycerides and Cholesterol in hyperglycaemic mice. The $R$. stricta leaves extract being most active was further fractionated by solvent extraction using n- Hexane, ethyl acetate, chloroform and water and all fractions were tested for same activities. It was found that ethyl acetate fraction is most effective in the reduction of blood glucose level at fasting and random conditions and blood glucose reduction was comparable to Glucophage, a standard antidiabetic drug. The present study suggests that Rhazya stricta leaves extract and its ethyl acetate fraction has great potential for development of antidiabetic drug.
\end{abstract}

Key Words: Anidiabetic, plant extract, fruit, leaves, Rhazya stricta Decne, polarity based extracts.

\section{INTRODUCTION}

Diabetes mellitus is a foremost endocrine syndrome upsetting nearly $10 \%$ of the people all over the world (Burke et al., 2003). Diabetes is one of the prominent origins of bereavement in humans and animals. In animals, it takes place most habitually in the dog with an incidence of approximately $0.2 \%$. According to National Institute of Diabetes and Endocrinology, Pakistan has an average of $7.6 \%$ diabetic population in it while in 2030, it will be $4^{\text {th }}$ principal diabetic populace in the domain with about 13.8 million diabetic people. Presently among 88,000 diabetic people in Pakistan, 35,615 are men while 52,397 are women. In the indigenous Indian system of medicine, good number of plants were cited for the cure of diabetes and some of them have been experimentally assessed and dynamic principle were quarantined (Grover et al., 2001; WHO, 1980) has also been suggested for the estimation of the effectiveness of plants in situations where there are no non-violent up-to-theminute remedies (Upadhaya and Pandey, 1984). The ethanobotanical evidence informations state that about 800 plants may possess antidiabetic potential (Al-Yahya et al., 1990). Freshly the medicinal values of innumerable plants extracts have been studied by many scientists in the field of diabetic research (Daisy and Eliza, 2007; Noor et al., 2008). Countless parts of herbs have been used for medicinal purposes as well as the treatment of diabetes mellitus. Among all type of diabetes, type 2 diabetes is main impediment due to adverse effects of treatment

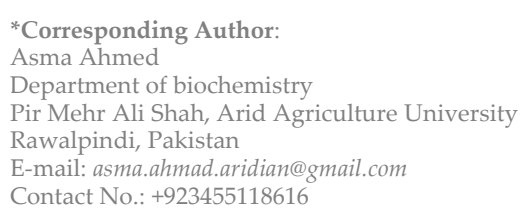

options in modern medicine. Therefore, there is a need to develop safe and effective treatment modalities for diabetes. Many developing countries are curing diabetes mellitus by using medicinal plants because they have very low income to treat it with allopathic medicines (Jaya, 2013).

Oleuropeoside showed maximum hypoglycaemic activity of winter Olive leaf at $16 \mathrm{mg} / \mathrm{kg}$ in Alloxan induced diabetetic rats due to potentiation of glucoseinduced insulin release and increased peripheral uptake of glucose (Gonzalez et al., 1992).

As many diabetic patients in the UAE use medicinal plants to treat diabetes with insulin or oral hypoglycaemic medicines, so effect of Rhazya stricta extract and glibenclamide, on the concentrations of glucose, insulin and glucagon in plasma and blood, respectively, has been examined by simultaneous treatment of streptozotocindiabetic rats. Amounts of $\mathrm{C}_{6} \mathrm{H}_{12} \mathrm{O}_{6}$, insulin or glucagon in Control rats were not affected significantly with the extract at oral doses of $0.5,20$ and $4.0 \mathrm{~g} / \mathrm{kg}$ for up to 4 hours extract post- administration while in diabetic rats it reduced the concentration of glucose after $1 \mathrm{~h}(2$ and 4 $\mathrm{g} / \mathrm{kg})$ and $2 \mathrm{~h}(4 \mathrm{~g} / \mathrm{kg})$ which was supplemented by maximum increases in the level of insulin after 1,2 and 4 hours of extract directions at doses of 2 and $4 \mathrm{~g} / \mathrm{kg}$. In normal and diabetic rats, Glibenclamide at 2.5, 5.0 and $10.0 \mathrm{mg} / \mathrm{kg}$ reduced levels of glucose and glucagon and increased insulin concentration. When normal and diabetic rats were treated with plant extract at 0.5, 20 and $5.0 \mathrm{~g} / \mathrm{kg}$ and glibenclamide, simultaneously, at $5.0 \mathrm{mg} / \mathrm{kg}$ significantly aggravated the effects on glucose, insulin and glucagon separately. When the plant extract at doses of $0.5,2$ and $4 \mathrm{~g} / \mathrm{kg} /$ day for six consecutive days, the glucose level was reduced by $6 \%, 8 \%$ and $30 \%$, one-toone. These results may suggest that administration of the 
extract and glibenclamide simultaneously might badly interfere with glucose control in diabetic patients (Ali, 1997).

1. This study was designed for the evaluation of antidiabetic activity of Rhazya stricta Decne

2. This study was also designed to assess effects of plant extracts on various blood parameters of animal models

\section{MATERIALS AND METHODS}

The whole study was supervised by corresponding author at each stage for the collection, verification and authentication of results.

\section{Collection of plant material}

The whole plant of Rhazya stricta Decne, were collected from Khoshab (District Khoshab) in dully labelled (Name of plant sample, area of collection and date of collection) fine plastic bags. Plant samples were identified by expert taxonomist, from the Department of Botany, PMAS AAUR and their voucher specimens were registered in the Botanical garden of Pir Mehr Ali Shah Arid Agriculture University with voucher No. 001, 2010, A. Ahmed, BCH, Ph.D.1 ${ }^{\text {st }}$, for future studies.

\section{Preparation of plant samples}

Plant samples was shade dried followed by oven drying at $40^{\circ} \mathrm{C}$. Leaves and fruit were separated out and ground into powder with the help of a grinder and passed through 80 mesh sieve. Latter it was stored at lower temperature in air tight bottles for further use.

\section{Antidiabetic activity of crude plant extracts on animal models}

Antidiabetic assay was performed in the animal house of National Veterinary Laboratories, Chak Shahzad, Islamabad. Adult albino mice Balb- $\mathrm{C}$ weighing about 30$40 \mathrm{~g}$ were used and they were kept under the rules of Ethics Committees on Animals by National veterinary laboratory, Islamabad, during the whole study. All mice were given a period of acclimatization for 30 days before starting the experiment. Mice were kept in separate cages to prevent mating of mice. All mice were fed with poultry feed No. 1 daily and free access to water. Fasting animals were not given any food, except drinking water, for at least 8 hours.

\section{Induction of diabetes in animal models}

Animals were divided into four groups. Group 1 was serving as negative control or vehicle and was given only $0.4 \mathrm{ml}$ of $0.1 \mathrm{M}$ citrate buffer $(\mathrm{pH}=4.5) / \mathrm{Kg} \mathrm{b.w}$ of mice. Group 2 was given only $0.4 \mathrm{ml}$ of freshly prepared STZ $/ \mathrm{Kg} \mathrm{b.w}$ of mice and this group served as positive control for diabetes. Concentration for STZ used was $7 \mathrm{mg}$ STZ/ $\mathrm{ml}$ of citrate buffer. Group 3 served as positive control for antidiabetic drug Glucophage (Prepared in $0.1 \mathrm{M}$ citrate buffer ( $\mathrm{pH} 4.5)$ at a concentration of $1 \mathrm{mg}$ glucophage/ $\mathrm{ml}$ of citrate buffer). Group 4 and 5 were experimental groups and were injected with fruit and leave extracts, respectively at a dose of $1 \mathrm{mg} / \mathrm{kg}$ b.w of animal. Group 2 to 5 were made diabetic prior to one hour of induction of standard antidiabetic drug (Glucophage) (for group 3 only) and plant extracts (group 4 and 5 only). Diabetes was confirmed by the determination of fasting (8- 12 hours) and random (after 2 hour of feed intake). Glucose concentration in blood was assessed for 3 consecutive days after administration of streptozotocin for the confirmation of diabetes.

\section{Preparation of crude methanolic extracts}

Crude extracts of fruit and leaves of Rhazya stricta Decne were prepared in Agriculture Biochemistry lab, UIBB, PMAS AAUR, by dissolving $5 \mathrm{~g}$ (80 mesh) samples in 50 $\mathrm{ml} 80 \%$ methanol. Supernatant was saved while residue was again passed through $80 \%$ methanol and again supernatant was saved. Residue was discarded and supernatant was evaporated to make concentrated extracts and were saved at $4^{\circ} \mathrm{C}$ for further assay.

\section{Antidiabetic activity evaluation}

For the evaluation of antidiabetic activity of crude extracts of fruit and leaves of plant samples, following parameters were studied in details. Doses were administered intraperitoneally and blood sample was collected from tail and heart of the animal.

\section{Body weight measurement}

Body weight of mice was measured daily in random and fasting conditions, by using weighing balance.

\section{Oral glucose tolerance test (OGTT)}

This test was performed to check which animal can become diabetic most rapidly as compared to the rest of mice. For the 6 hour fast, animals were kept in the lab between 8-9 am and began the fast. Animals were kept on the same bench where experiments were performed so that they could be familiar to the area to reduce stress during the procedure. Weighed each mouse (weight determined amount of glucose to inject) and marked their bellies. In the morning before the procedure, $10 \%$ glucose solution was prepared and then QS to $10 \mathrm{~mL}$ with water. Blood glucose level was measured and glucose solution was filled in syringe (1 unit glucose solution to 1 gram of weight). Experiment time when started soon after the induction of glucose solution and concentration of glucose in blood animals was assessed. However glucose injections were injected to animals after 30, 60 and 120 minutes followed by the determination of blood glucose concentration for the evaluation of diabetic condition of animals.

\section{Blood glucose level test}

Blood glucose levels have been measured by pre calibrated Glucometer (EUSURE, SN: T044040130029).

\section{Glycosylated haemoglobin test}

Glycosylated Haemoglobin has been measured by Kit method (after collecting whole blood from the mice in random condition.

\section{Blood cholesterol level test}

In a representative inspect, $0.1 \mathrm{ml}$ of plasma or serum, 0.3 $\mathrm{ml}$ of $33.00 \%(\mathrm{w} / \mathrm{v}) \mathrm{KOH}$, and $3 \mathrm{ml}$ of $95.00 \%$ ethanol were positioned and assorted meticulously. The tube was then capped and engaged in a $60^{\circ} \mathrm{C}$ cooking wedge for 15 minutes. After the assortment has been chilled, $10.00 \mathrm{ml}$ of hexane was compellingly auxiliary to the tube to mix with the junior deposit and $3.00 \mathrm{ml}$ of distilled water was additional, capped and shake for 1 minute to confirm farreaching mingling. A blank, a standard, and a sample of united plasma were saponified and haul out side by side. Apposite aliquots (generally $1 \mathrm{ml}$ ) of the hexane layer were pipetted in replica into colorimeter tubes, and solvent was faded under nitrogen. $2.00 \mathrm{ml}$ of the o- 
phthalaldehyde reagent was supplementary to per capita and the way out was systematically diversified to thaw the entire sample. About $10.00 \mathrm{~min}$ after the totalling of the o-phthalaldehyde reagent, $1.00 \mathrm{ml}$ of concentrated $\mathrm{H}_{2} \mathrm{SO}_{4}$ was cautiously added by permitting it to run down the inside of the tube; the solutions were instantaneously varied on a tube vibrator. Then absorbance was recorded at $550 \mathrm{~nm}$ amongst 10.00 and 90.00 minutes after the accumulation of the conc. $\mathrm{H}_{2} \mathrm{SO}_{4}$.

\section{Triglyceride level test}

Seven test tubes was categorized, alpha, beta for analysis 1 , chalie, delta for experiment 2, epsilon, gamma for the standard, and gaga for the blank and $1.0 \mathrm{ml}$ of sample was added in tube A (Alpha or $\alpha$ ) and B (Beta or $\beta$ ), followed by the addition of samples in tubes $C$ (Charlie or $C$ ) and $D$ (Delta or $\delta$ ). Standard cholesterol was added in tube $\mathrm{E}$ (Epsilon or $\epsilon$ ) and $F$ (gamma or $\gamma$ ) while distilled water was added in tube $\mathrm{G}$ (gaga). Then cholesterol reagent was added in all tubes and tubes were gestated at $25^{\circ} \mathrm{C}$ for twenty minutes. $1.0 \mathrm{ml}$ of $\mathrm{H}_{2} \mathrm{SO}_{4}$ was supplemented to every one Test. All tubes were nurtured in a water bath at $25^{\circ} \mathrm{C}$ for 15.00 minutes. They were disinterested from the water bath and shake forcefully. Absorbance was dignified after 10 minutes for the samples in contradiction of the blank at $610 \mathrm{~nm}$. Calculation was done by using following formulas:

(Sample Absorbance/ Absorbance of standard) $\times 300$

$(\alpha+\beta / 2)=(0.222+0.189 / 2)=0.411 / 2=0.2055$ SAMPLE 01.

$(C+\delta / 2)=(0.322+0.386 / 2)=0.708 / 2=0.354$ SAMPLE 02.

$(\epsilon+\gamma / 2)=(0.237+0.439 / 2)=0.676 / 2=0.338$ STANDARD.

The ordinary amount of cholesterol was 150.00 to 250.00 $\mathrm{mg} / \mathrm{dl}$.

\section{Blood urea level test}

Tris (hydroxymethyl) amino ethane, urease and J3mercaptoethanol were acquired from Sigma Chemical Corporation USA and gum cast-off was from Unicol, PSV India. All other substances used were of systematic grade. Urea strips were prepared when Urease $(10.00 \mathrm{mg}$, specific activity of $1500.00 \mathrm{Ul} \mathrm{mg}$ protein) was dissolved in $10 \mathrm{ml}$ of $25.00 \mathrm{mM}$ Tris acetate buffer ( $\mathrm{pH} 5.5) .5 \mathrm{mg}$ of phenol red dye was supplemented and diversified systematically to make a standardized solution. The constancy of the enzyme was greater than before by adding $100.00 \mathrm{ILl} 13$-mercaptoethanol and rotated at 5000 rpm for $5 \mathrm{~min}$ to achieve a vibrant enzyme solution. Whitman No.1 filter paper $(5 \times 45 \mathrm{~cm}$.) was layered with enzyme dye solution and desiccated at $30^{\circ} \mathrm{C}$ in moisture free compartment. The shade of the paper transformed to yellow afterwards whole freshening. The paper was cut at $5 \mathrm{~mm}$. width into numerous fragments by appropriate premeditated reaper.

\section{Preparation of polarity based extracts}

Polarity based extracts of leaves of Rhazya stricta Decne were prepared in Agriculture Biochemistry lab, UIBB, PMAS AAUR, by dissolving 80 mesh samples in pure solvent (Less polar to more polar), mean in n- Hexane, Ethyl acetate, Chloroform and water, respectively. Supernatant was saved while residue was again passed through same solvent by repeating the same procedure and again supernatant was saved. Residue was used for next more polar solvent. Supernatant was evaporated to make concentrated extracts and later on they were saved at $4^{\circ} \mathrm{C}$ for antidiabetic assay.
Table 1: Qualitative analysis of phytochemicals of $R$. stricta.

\begin{tabular}{ccc}
\hline \multirow{2}{*}{ Phytochemicals } & \multicolumn{2}{c}{ Plant Parts } \\
\cline { 2 - 3 } & Leaves & Fruits \\
\hline Alkaloids & + & + \\
Flavonoids & + & + \\
Phenols & + & + \\
Saponin & + & + \\
Tannins & + & + \\
\hline += Present & $-=$ Absent &
\end{tabular}

Antidiabetic activity of polarity based extracts of Rhazya stricta Decne leaves

For the evaluation of antidiabetic activity of polarity based extracts of leaves of Rhazya stricta Decne, only blood glucose levels of mice were measured by using pre calibrated Glucometer (EUSURE, SN: T044040130029).

\section{Statistical analysis}

All results obtained were analysed by Appling analysis of variance (ANOVA) in which Completely Randomized Design was used to compare the results of plant extracts and then all plant samples used. More over data obtained was further checked by doing Duncan's Multiple Range Test (DMRT) in MSTAT- C software. Mean and standard deviation was also measured to check and confirm the significance of replicates.

\section{RESULTS AND DISCUSSION}

Qualitative analysis of phytochemicals in all plant samples

It came to know that all tested phytochemicals were indicated in leaves and fruit samples of Rhazya stricta Decne (table 1). There is a plethora of studies on the phytochemical constituents of the leaves, fruits, legumes and roots of $R$. stricta in which several types of alkaloids and a few flavonoids have been isolated and their structure elucidated (Atta-ur-Rahman et al., 2004; Muhammad et al., 2013). Fruit and leaves are used for edible purposes due to presence of high percentage of various nutritive constituent i.e. protein, fiber, palmetine, calcium, sulphur, berbarine and vitamin $\mathrm{C}$.

\section{Antidiabetic activity of plant samples}

Oral glucose tolerance test (OGTT) was performed to check which animals can develop diabetes more rapidly. Among tested animals, those male mice were used to develop for diabetes whose blood glucose level was more than $130 \mathrm{mg} / \mathrm{dl}$ while those female mice were used to develop diabetes whose blood glucose level was more than $220 \mathrm{mg} / \mathrm{dl}$ in OGTT (table 2).

Results of Blood glucose concentration of tested animals showed that in males during fasting condition, leaves of $R$. stricta reduced blood glucose level more rapidly than other plants parts and then its own fruit because blood glucose concentration was found to be $146.00 \pm 40.36 \mathrm{mg} / \mathrm{dl}$ and $162.32 \pm 41.078$ in male and female mice, respectively in fasting conditions while it was found to be $125.34 \pm 63.79 \mathrm{mg} / \mathrm{dl}$ and $107.34 \pm 18.00 \mathrm{mg} / \mathrm{dl}$ in male and female mice, respectively in random conditions. These blood glucose was lowered almost as much as the glucophage has done in which blood glucose was lowered up to $84.67 \pm 21.78 \mathrm{mg} / \mathrm{dl}$ and $85.00 \pm 25.06$ in male and female mice, respectively in fasting conditions while it was found to be $104.67 \pm 36.29 \mathrm{mg} / \mathrm{dl}$ and $92.95 \pm 9.5 \mathrm{mg} / \mathrm{dl}$ in male and female mice, respectively in random conditions (table 3). 
Table 2: Blood glucose levels of selected mice for assessment of oral glucose tolerance test (OGTT).

\begin{tabular}{|c|c|c|c|c|c|c|}
\hline \multirow{2}{*}{ Group } & \multirow{2}{*}{ Sex } & \multicolumn{5}{|c|}{ Blood glucose levels (mg/dl) } \\
\hline & & $0 \mathrm{~min}$ & $30 \mathrm{~min}$ & $60 \mathrm{~min}$ & $90 \mathrm{~min}$ & $120 \mathrm{~min}$ \\
\hline \multirow{2}{*}{1 (Negative control) } & $\mathrm{M}$ & $110.34 \pm 56.88$ & $136 \pm 78.9$ & $117 \pm 60.00$ & $130.34 \pm 54.81$ & $91 \pm 21.74$ \\
\hline & $\mathrm{F}$ & $186.67 \pm 59.09$ & $212.34 \pm 21.36$ & $203.67 \pm 14.46$ & $195.67 \pm 29.02$ & $166.67 \pm 32.25$ \\
\hline \multirow{2}{*}{2 (Diabetic control) } & M & $151.67 \pm 14.64$ & $313.34 \pm 63.50$ & $236.34 \pm 68.38$ & $245.67 \pm 87.37$ & $120.67 \pm 51.29$ \\
\hline & $\mathrm{F}$ & $259.67 \pm 53.45$ & $234 \pm 17.22$ & $237.34 \pm 14.21$ & $249 \pm 76.39$ & $185.67 \pm 24.54$ \\
\hline \multirow{2}{*}{3 (Antidiabetic control) } & M & $218 \pm 40.58$ & $183 \pm 35.38$ & $223.34 \pm 67.30$ & $110.34 \pm 57.735$ & $152.67 \pm 40.69$ \\
\hline & $\mathrm{F}$ & $198.67 \pm 57.07$ & $244.67 \pm 37.93$ & $233.34 \pm 14.20$ & $218 \pm 44.69$ & $233.67 \pm 84.60$ \\
\hline \multirow{2}{*}{4 (R. stricta Fruit) } & M & $218 \pm 40.58$ & $183 \pm 35.38$ & $223.34 \pm 67.30$ & $110.34 \pm 57.7$ & $152.67 \pm 40.69$ \\
\hline & $\mathrm{F}$ & $186.67 \pm 59.07$ & $212.34 \pm 21.36$ & $203.67 \pm 14.46$ & $195.67 \pm 29.02$ & $166.67 \pm 32.25$ \\
\hline \multirow{2}{*}{5 (R. stricta Leave) } & M & $110.34 \pm 56.88$ & $136 \pm 78.93$ & $117 \pm 60.008$ & $130.34 \pm 54.81$ & $120.67 \pm 51.29$ \\
\hline & $\mathrm{F}$ & $259.67 \pm 53.45$ & $234 \pm 17.22$ & $237.34 \pm 14.21$ & $249 \pm 79.39$ & $185.67 \pm 24.54$ \\
\hline
\end{tabular}

$\pm=$ Values obtained after triplicate analysis, $\mathrm{M}=$ Male, $\mathrm{F}=$ Female

Table 3: Concentration of glucose $(\mathrm{mg} / \mathrm{dl})$ in various groups of animals after the induction of anitidiabetic standard and plant extracts.

\begin{tabular}{|c|c|c|c|c|c|c|c|c|c|}
\hline \multirow{2}{*}{ Groups } & \multirow{2}{*}{ Sex } & \multicolumn{2}{|c|}{ Normal } & \multicolumn{2}{|c|}{ STZ } & \multicolumn{2}{|c|}{ Glucophage } & \multicolumn{2}{|c|}{ Plant extracts } \\
\hline & & Random & Fasting & Random & Fasting & Random & Fasting & Random & Fasting \\
\hline Group 3 & $\mathrm{M}$ & $221.33 \pm 50.16$ & $200 \pm 21.79$ & $262 \pm 81.26$ & $212.667 \pm 67.26$ & $104.67 \pm 36.29$ & $84.67 \pm 21.78$ & & \\
\hline (Glucophage) & $\mathrm{F}$ & $210.34 \pm 11.15$ & $169 \pm 31$ & $169.33 \pm 33.86$ & $97.34 \pm 48.41$ & $92.95 \pm 9.5$ & $85 \pm 25.06$ & & \\
\hline Group 4 & M & $143.23 \pm 55.05$ & $228.67 \pm 38.53$ & $303.34 \pm 52.12$ & $359.34 \pm 34.19$ & & & $226.67 \pm 14.15$ & $263.61 \pm 61.62$ \\
\hline (R. stricta Fruit) & $\mathrm{F}$ & $173.66 \pm 49.09$ & $206.65 \pm 6.65$ & $289 \pm 53.55$ & $283.34 \pm 5.68$ & & & $192.34 \pm 28.92$ & $219 \pm 77.62$ \\
\hline Group 5 & M & $230 \pm 40.14$ & $316.67 \pm 15.04$ & $348.67 \pm 51.82$ & $344 \pm 31$ & & & $125.34 \pm 63.79$ & $146.00 \pm 40.36$ \\
\hline (R. stricta Leaves) & $\mathrm{F}$ & $171.67 \pm 21.36$ & $206.34 \pm 28.29$ & $260.67 \pm 51.04$ & $289.67 \pm 64.36$ & & & $107.34 \pm 18.00$ & $178.34 \pm 17.03$ \\
\hline
\end{tabular}

$\pm=$ Values obtained after triplicate analysis, M= Male, F= Female

Table 4: Amount of glycated haemoglobin (HBA1c, \%) in various groups of animals after the induction of anitidiabetic standard and plant extracts.

\begin{tabular}{|c|c|c|c|c|c|c|}
\hline \multirow{2}{*}{ Groups } & \multirow{2}{*}{\multicolumn{2}{|c|}{ Buffer }} & \multirow{3}{*}{ STZ } & \multirow{2}{*}{ Glucophage } & \multicolumn{2}{|c|}{ R. Stricta } \\
\hline & & & & & Leaves & Fruit \\
\hline Group 1 & M & $6 \pm 0.3$ & & & & \\
\hline (Negative control) & $\mathrm{F}$ & $6.1 \pm 1.56$ & & & & \\
\hline Group 2 & M & & $10.84 \pm 3.94$ & & & \\
\hline (Diabetic control) & $\mathrm{F}$ & & $10.27 \pm 2.12$ & & & \\
\hline Group 3 & $\mathrm{M}$ & & & $6.1 \pm 1.13$ & & \\
\hline (Antidiabetic control) & $\mathrm{F}$ & & & $6.17 \pm 1.58$ & & \\
\hline Group 4 & M & & & & $6.3 \pm 0.7$ & \\
\hline (R. stricta Leaves) & $\mathrm{F}$ & & & & $6.6 \pm 0.1$ & \\
\hline Group 5 & M & & & & & $8.54 \pm 0.94$ \\
\hline (R. stricta Fruits) & $\mathrm{F}$ & & & & & $9.54 \pm 1.53$ \\
\hline
\end{tabular}

$\pm=$ Values obtained after triplicate analysis, $\mathrm{M}=$ Male, F= Female

Table 5: Amount of total cholesterol (mg/dl) in various groups of animals after the induction of anitidiabetic standard and plant extracts.

\begin{tabular}{|c|c|c|c|c|c|c|}
\hline \multirow{2}{*}{\multicolumn{2}{|c|}{ Groups }} & \multirow{2}{*}{ Buffer } & \multirow{2}{*}{ STZ } & \multirow{2}{*}{ Glucophage } & \multicolumn{2}{|c|}{ R. Stricta } \\
\hline & & & & & Leaves & Fruit \\
\hline Group 1 & $\mathrm{M}$ & $147.88 \pm 21.83$ & & & & \\
\hline (Negative Control) & $\mathrm{F}$ & $125.89 \pm 14.03$ & & & & \\
\hline Group 2 & $\mathrm{M}$ & & $261.34 \pm 47.74$ & & & \\
\hline (Diabetic control) & $\mathrm{F}$ & & $290.89 \pm 34.25$ & & & \\
\hline Group 3 & $\mathrm{M}$ & & & $107.13 \pm 20.00$ & & \\
\hline (Antidiabetic control) & $\mathrm{F}$ & & & $134.31 \pm 31.01$ & & \\
\hline \multirow{2}{*}{ Group 4} & $\mathrm{M}$ & & & & $147.88 \pm 21.83$ & \\
\hline & $\mathrm{F}$ & & & & $125.89 \pm 14.03$ & \\
\hline \multirow{2}{*}{ Group 5} & M & & & & & $261.34 \pm 47.74$ \\
\hline & $\mathrm{F}$ & & & & & $290.89 \pm 34.25$ \\
\hline
\end{tabular}

$\pm=$ Values obtained after triplicate analysis, $\mathrm{M}=$ Male, $\mathrm{F}=$ Female 
Table 6: Amount of Serum lipids (triacylglycerides $(\mathrm{mg} / \mathrm{dl})$ in various groups of animals after the induction of anitidiabetic standard and plant extracts.

\begin{tabular}{|c|c|c|c|c|c|c|}
\hline \multirow{2}{*}{\multicolumn{2}{|c|}{ Groups }} & \multirow{2}{*}{ Buffer } & \multirow{2}{*}{ STZ } & \multirow{2}{*}{ Glucophage } & \multicolumn{2}{|c|}{ R. Stricta } \\
\hline & & & & & Leaves & Fruit \\
\hline Group 1 & M & $135.31 \pm 19.33$ & & & & \\
\hline (Negative Control) & $\mathrm{F}$ & $146.44 \pm 38.49$ & & & & \\
\hline Group 2 & M & & $181.85 \pm 21.96$ & & & \\
\hline (Diabetic control) & $\mathrm{F}$ & & $234.04 \pm 56.42$ & & & \\
\hline Group 3 & $\mathrm{M}$ & & & $143.15 \pm 24.39$ & & \\
\hline (Antidiabetic control) & $\mathrm{F}$ & & & $128.93 \pm 14.65$ & & \\
\hline Group 4 & $\mathrm{M}$ & & & & $103 \pm 8.88$ & \\
\hline & $\mathrm{F}$ & & & & $89 . \pm 43.4$ & \\
\hline Group 5 & $\mathrm{M}$ & & & & & $137.19 \pm 44.94$ \\
\hline & $\mathrm{F}$ & & & & & $116.93 \pm 65.02$ \\
\hline
\end{tabular}

$\pm=$ Values obtained after triplicate analysis, $\mathrm{M}=$ Male, $\mathrm{F}=$ Female

Table 7: Amount of Total Urea (mg/dl) in various groups of animals after the induction of anitidiabetic standard and plant extracts.

\begin{tabular}{|c|c|c|c|c|c|c|}
\hline \multirow{2}{*}{\multicolumn{2}{|c|}{ Groups }} & \multirow{2}{*}{ Buffer } & \multirow{2}{*}{ STZ } & \multirow{2}{*}{ Glucophage } & \multicolumn{2}{|c|}{ R. Stricta } \\
\hline & & & & & Leaves & Fruit \\
\hline Group 1 & $\mathrm{M}$ & $27 \pm 2.64$ & & & & \\
\hline (Negative Control) & $\mathrm{F}$ & $33.34 \pm 1.53$ & & & & \\
\hline Group 2 & $\mathrm{M}$ & & $40.67 \pm 3.78$ & & & \\
\hline (Diabetic control) & $\mathrm{F}$ & & $59.34 \pm 7.51$ & & & \\
\hline Group 3 & M & & & $32.67 \pm 1.53$ & & \\
\hline (Antidiabetic control) & $\mathrm{F}$ & & & $35 \pm 3$ & & \\
\hline Group 4 & M & & & & $27.9 \pm 16.96$ & \\
\hline & $\mathrm{F}$ & & & & $29.5 \pm 12.67$ & \\
\hline Group 5 & M & & & & & $35.67 \pm 2.08$ \\
\hline Group 5 & $\mathrm{~F}$ & & & & & $33.34 \pm 1.53$ \\
\hline
\end{tabular}

$+ \pm=$ Values obtained after triplicate analysis, $\mathrm{M}=$ Male, $\mathrm{F}=$ Female

Table 8: Blood glucose concentration $(\mathrm{mg} / \mathrm{dl})$ after treatment with polarity based extracts of $\mathrm{R}$. stricta Decne leaves.

\begin{tabular}{|c|c|c|c|c|c|c|c|c|c|}
\hline \multirow[t]{2}{*}{ GROUPS } & \multirow[t]{2}{*}{ ふัّ } & \multicolumn{2}{|c|}{$\begin{array}{c}\text { Blood glucose } \\
\text { concentration }(\mathrm{mg} / \mathrm{dl}) \\
\text { (normal) }\end{array}$} & \multicolumn{2}{|c|}{$\begin{array}{c}\text { Blood glucose } \\
\text { concentration (mg/dl) } \\
\text { (STZ) }\end{array}$} & \multicolumn{2}{|c|}{$\begin{array}{c}\text { Blood glucose } \\
\text { concentration (mg/dl) } \\
\text { (Glucophage) }\end{array}$} & \multicolumn{2}{|c|}{$\begin{array}{c}\text { Blood glucose } \\
\text { concentration (mg/dl) } \\
\text { (Plant extract) }\end{array}$} \\
\hline & & Random & Fasting & Random & Fasting & Random & Fasting & Random & Fasting \\
\hline \multirow{2}{*}{$\begin{array}{c}\text { Group } 3 \\
\text { (Glucophage) }\end{array}$} & M & $219 \pm 70.71$ & $195 \pm 28.28$ & $81.26 \pm 26$ & $212.67 \pm 67.26$ & $104.67 \pm 36.29$ & $84.67 \pm 21.78$ & & \\
\hline & F & $223 \pm 2.82$ & $174.5 \pm 41.72$ & $169.34 \pm 33.85$ & $9737 \pm 48.42$ & $92 \pm 9.5$ & $85 \pm 25.96$ & & \\
\hline $\begin{array}{l}\text { Group } 4 \\
\text { (R. stricta) }\end{array}$ & M & $200 \pm 36.06$ & $209 \pm 25.45$ & $275.34 \pm 32.47$ & $312.34 \pm 32.81$ & & & $226.67 \pm 14.14$ & $252.34 \pm 43.62$ \\
\hline n- Hexane & F & $145.5 \pm 14.85$ & $207.5 \pm 9.19$ & $282 \pm 33.95$ & $289 \pm 17.45$ & & & $231 \pm 48.66$ & $196.34 \pm 50.06$ \\
\hline $\begin{array}{l}\text { Group } 5 \\
\text { (R. stricta) }\end{array}$ & M & $209.34 \pm 38.14$ & $232.17 \pm 85.17$ & $254.67 \pm 52.29$ & $236 \pm 42.32$ & & & $152 \pm 11.53$ & $200 \pm 67.45$ \\
\hline Ethyl acetate & F & $133.67 \pm 53.16$ & $111.67 \pm 23.02$ & $287.67 \pm 29.19$ & $251 \pm 36.67$ & & & $168.34 \pm 29.57$ & $153.67 \pm 21.08$ \\
\hline $\begin{array}{l}\text { Group } 6 \\
(\text { R. stricta })\end{array}$ & M & $176.67 \pm 27.02$ & $223 \pm 46 . .23$ & $295 \pm 30.34$ & $280 \pm 29.46$ & & & $203.67 \pm 6.43$ & $208 \pm 32.36$ \\
\hline Chloroform & $\mathrm{F}$ & $100 \pm 45.03$ & $118 \pm 28.05$ & $290 \pm 29.71$ & $300 \pm 37,64$ & & & $231.67 \pm 74.61$ & $203.34 \pm 42$ \\
\hline $\begin{array}{l}\text { Group } 7 \\
\text { (R. stricta) }\end{array}$ & M & $207.34 \pm 77.15$ & $192 \pm 8$ & $303.34 \pm 45.36$ & $319.34 \pm 32.25$ & & & $236.67 \pm 23.63$ & $233.67 \pm 9.61$ \\
\hline Water & $\mathrm{F}$ & $128 \pm 6.55$ & $131.67 \pm 50$ & $268.67 \pm 33.97$ & $306.67 \pm 20.11$ & & & $215.67 \pm 61.04$ & $155.34 \pm 45.62$ \\
\hline
\end{tabular}

$\mathrm{N}=3$ and data obtained after triplicate analysis 


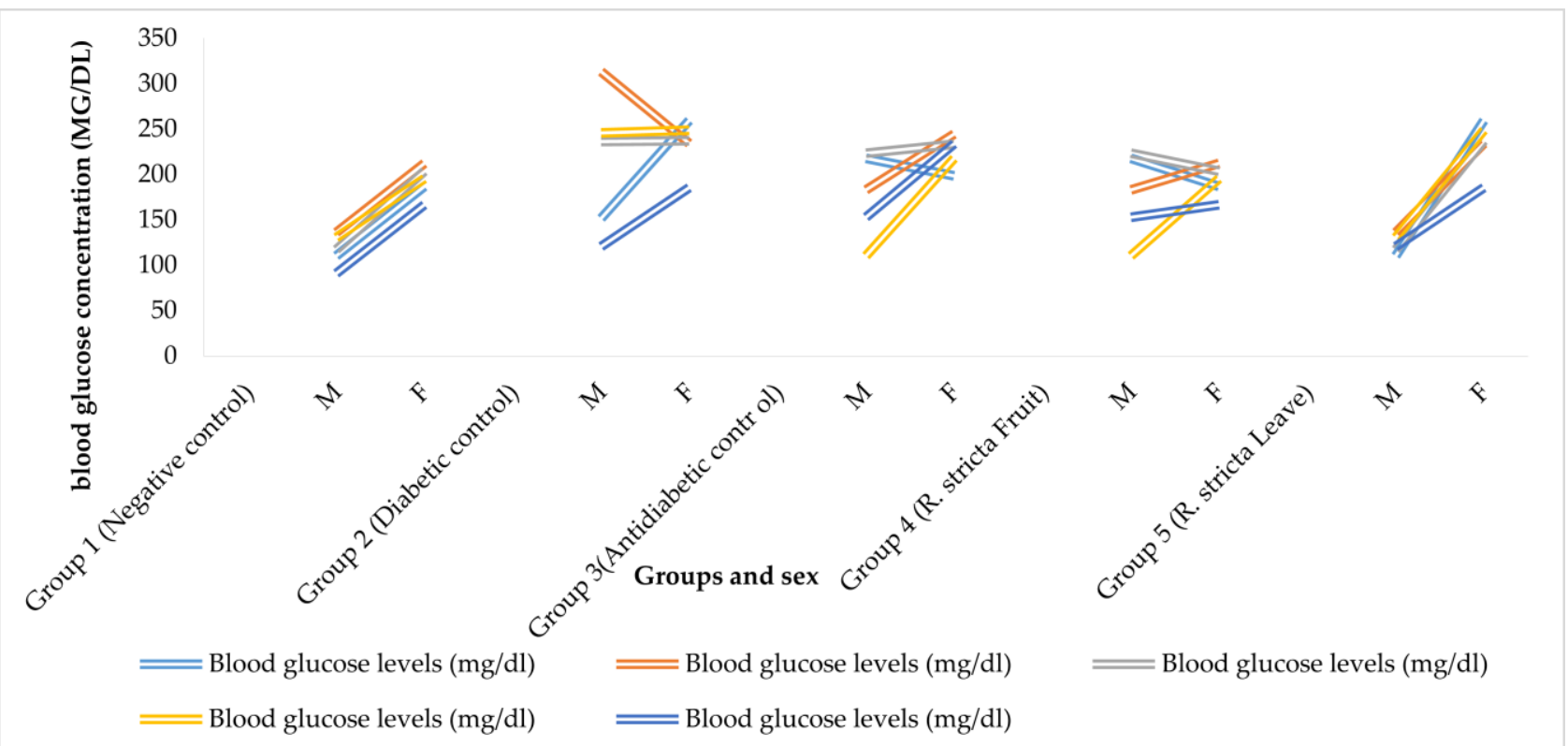

Figure 1: Blood glucose levels of selected mice for the induction of diabetes.

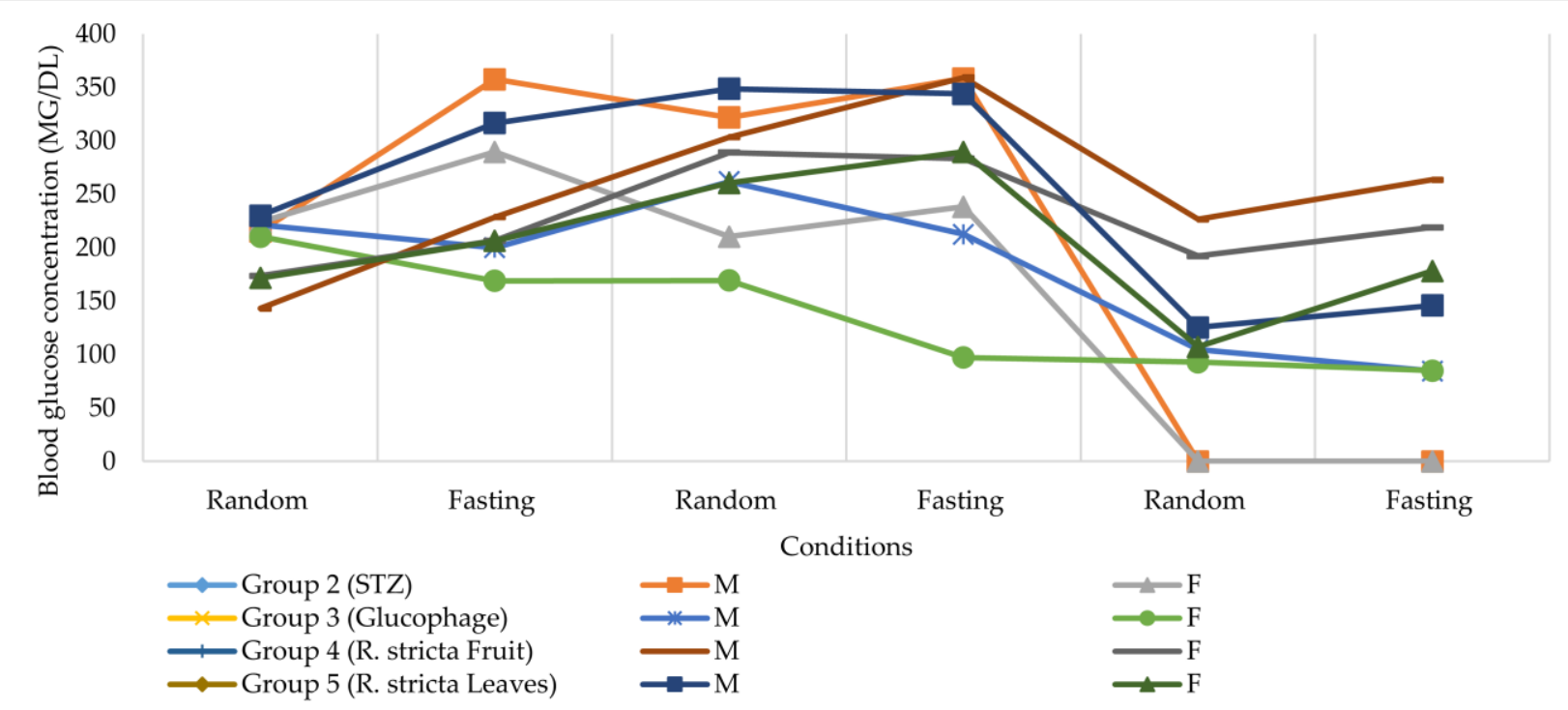

Figure 2: Concentration of glucose $(\mathrm{mg} / \mathrm{dl})$ in various groups of animals.

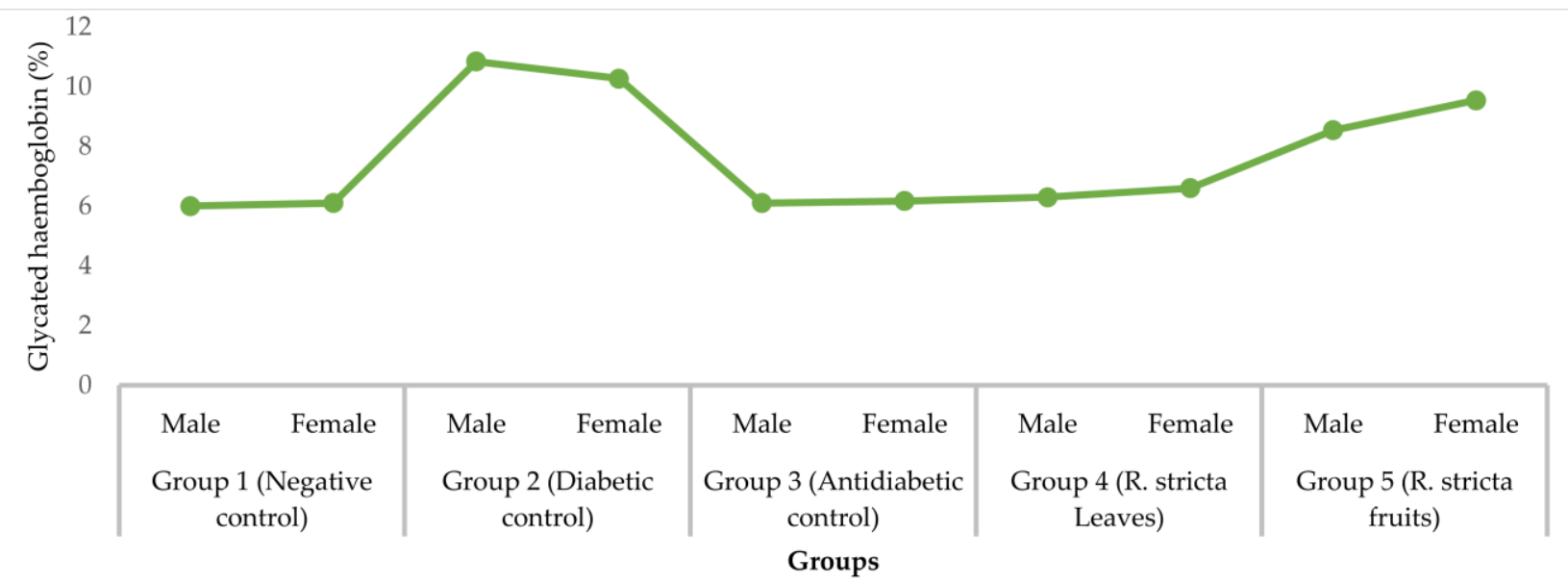

Figure 3: Glycated Haemoglobin (HBA1c, \%) in various groups of animals after the induction of anitidiabetic standard and plant extracts. 


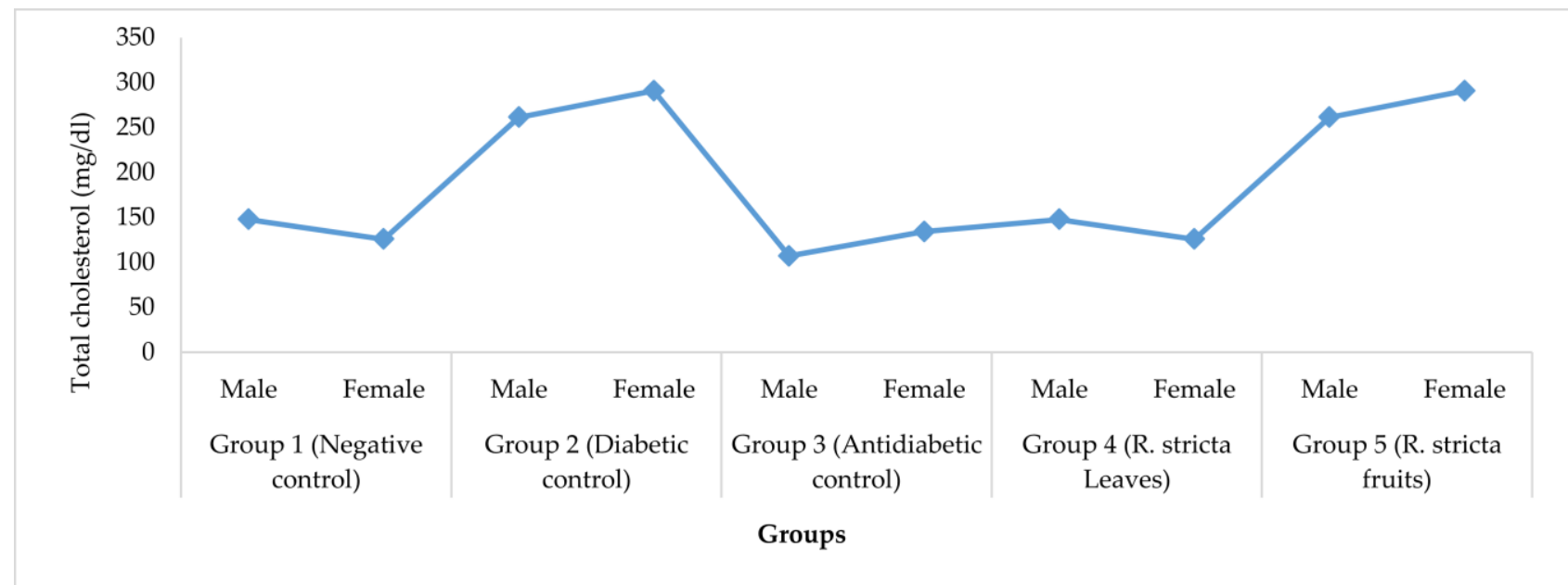

Figure 4: Total Cholesterol (mg/dl) in various groups of animals after the induction of anitidiabetic standard and plant extracts.

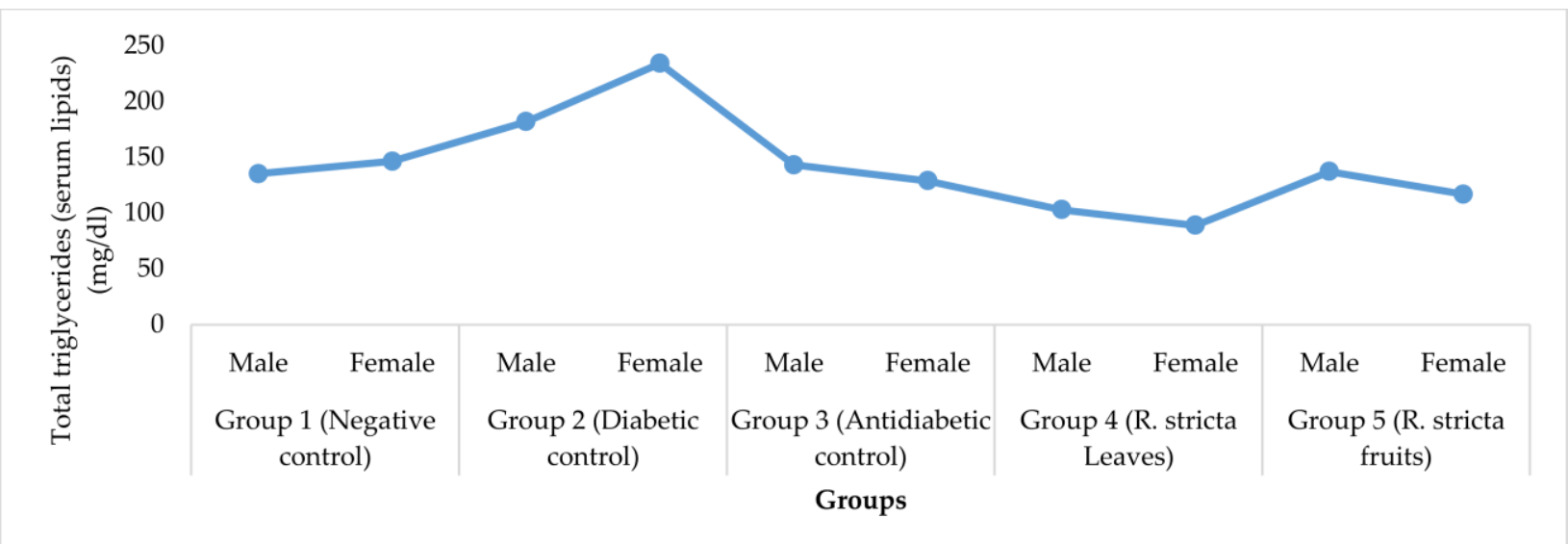

Figure 5: Serum lipids (triglycerides) $(\mathrm{mg} / \mathrm{dl})$ in various groups of animals after the induction of anitidiabetic standard and plant extracts.

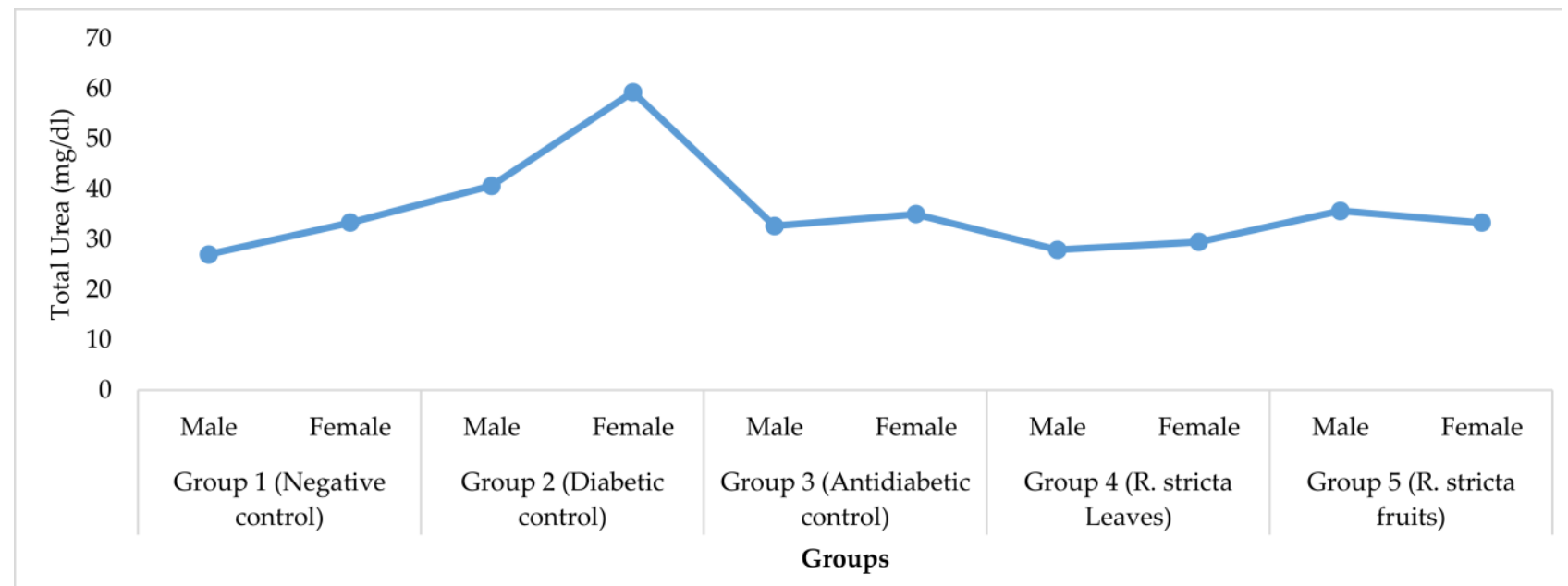

Figure 6: Amount of Total urea (mg/dl) in various groups of animals after the induction of anitidiabetic standard and plant extracts. 


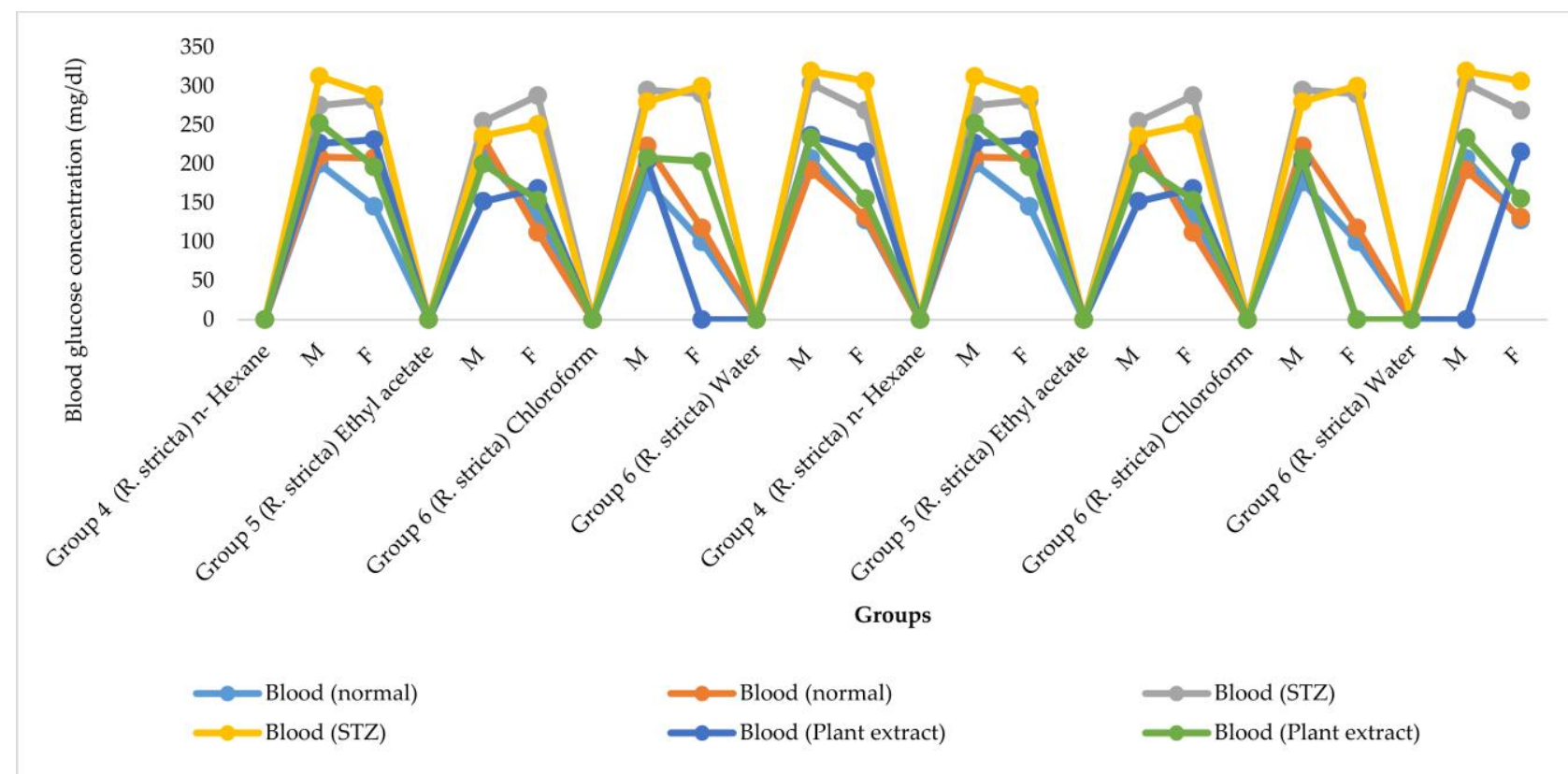

Figure 7: Blood Glucose Concentration (mg/dl) after treatment with Polarity Based Extracts of R. stricta Decne leaves.

Glycosylated haemoglobin was more strongly reduced by $R$. stricta leaves in which its amount was found to be $6.3 \pm 0.7 \%$ in males (table 4 ). $R$. stricta fruit were less effective in the reduction of glycosylated haemoglobin in male and female mice. Along with this statistical analysis showed that $R$. stricta fruit has equal ability to reduce glycosylated.

Amount of total cholesterol was more strongly reduced by $147.88 \pm 21.83 \mathrm{mg} / \mathrm{dl}$ and $125.89 \pm 14.03 \mathrm{mg} / \mathrm{dl}$ in male and female mice, respectively which were treated with $R$. stricta leaves in random conditions while $R$. stricta fruit was least effective to reduce blood cholesterol level (table 5). Statistical analysis of obtained results indicates that $R$. stricta fruit and leaves were reducing blood cholesterol level similarly.

As like cholesterol, amount of triacylglycerides was most strongly reduced by $R$. stricta leaves in random conditions in both male and female mice samples where triglyceride level was found to be $103.00 \pm 08.88 \mathrm{mg} / \mathrm{dl}$ and $89.00 \pm 43.4 \mathrm{mg} / \mathrm{dl}$, respectively while $R$. Stricta fruit was less effective in reducing blood triglyceride levels in males and females, respectively (table 6).

Like cholesterol and triglyceride levels, blood urea concentration was most strongly reduced by $R$. stricta leaves in random conditions in both male and female mice samples where urea concentration was found to be $27.9 \pm 16.96 \mathrm{mg} / \mathrm{dl}$ and $9.50 \pm 12.67 \mathrm{mg} / \mathrm{dl}$, respectively (table 7).

\section{Antidiabetic activity of polarity based extracts}

Although all extracts from leaves of $R$. stricta exhibited the activity of reduction in blood glucose, blood cholesterol, urea and glycosylated haemoglobin levels, however, leaves of $R$. stricta were founded more effective in this experiment and on the basis of this activity, leaves of $R$. stricta were used to check their blood glucose lowering activity in n- Hexane, ethyl acetate, chloroform and water extracts. Blood glucose lowering activity of these extracts were compared with negative control, positive diabetic control and positive antidiabetic controls also and it was found that ethyl acetate extract was more operative in the reduction of life blood glucose level at fasting condition $(200 \pm 67.45 \mathrm{mg} / \mathrm{dl}$ and $153.67 \pm 21.08 \mathrm{mg} / \mathrm{dl}$, respectively) and random conditions $(226.67 \pm 14.14 \mathrm{mg} / \mathrm{dl}$ and $231 \pm 48.66$ $\mathrm{mg} / \mathrm{dl}$ ) in both males and female mice and the amount of blood glucose was closed to the amount of blood glucose reduced by Glucophage at fasting condition $(84.67 \pm 21.78$ $\mathrm{mg} / \mathrm{dl}$ and $85 \pm 25.96 \mathrm{mg} / \mathrm{dl}$, respectively) and random conditions $(104.67 \pm 36.29 \mathrm{mg} / \mathrm{dl}$ and $92 \pm 9.5 \mathrm{mg} / \mathrm{dl})$ in both male and female mice (table 8). This blood glucose lowering activity of ethyl acetate extract was almost similar to the work represented by Yamauchi et al., (2003) who found there are likenesses in the properties of Rhazya stricta and adiponectin on diabetes, hypertension, carbohydrate metabolism, as well as inflammatory situations and animal studies for the conformation of antidiabetic effects of Rhazya stricta and adiponectin have proved that adiponectin eases elevated blood glucose levels in diverse models of fatness/diabetes mellitus. Water and n- Hexane extracts of $R$. stricta leaves were almost equally effective in the reduction of blood glucose levels of diabetic male and female mice (table 9).

Table 9: Blood glucose concentration $(\mathrm{mg} / \mathrm{dl})$ of polarity based extracts of $R$. stricta (Leave).

\begin{tabular}{|c|c|}
\hline GROUP & $\begin{array}{c}\text { DMRT } \\
\text { RESULT }\end{array}$ \\
\hline Group 1 (Buffer) & $151.0^{\mathrm{C}}$ \\
\hline Group 2 (STZ) & $323.9^{\mathrm{A}}$ \\
\hline Group 3 (Glucophage) & $226.6^{\mathrm{B}}$ \\
\hline Group 4 (n-Hexane extract of $R$. stricta (Leave) & $184.3^{\mathrm{BC}}$ \\
\hline Group 5 (Ehtyl acetate extract of $R$. stricta (Leave) & $91.58^{\mathrm{D}}$ \\
\hline Group 6 (Chloroform extract of $R$. stricta (Leave) & $195.8^{\mathrm{BC}}$ \\
\hline Group 7 (Water extract of $R$. stricta (Leave) & $210.3^{\text {B }}$ \\
\hline
\end{tabular}

$\mathrm{N}=3$ and data obtained after triplicate analysis; $\mathrm{A}=$ Maximum/ Highest blood glucose concentration; $\mathrm{B}=$ blood glucose concentration, higher than $\mathrm{C}$ but lower than $\mathrm{A} ; \mathrm{C}=$ blood glucose concentration, higher than $\mathrm{D}$ but lower than C; D= Least/ Lowest blood glucose concentration 


\section{CONCLUSION}

The leaves of $R$. stricta were most effective to reduce blood glucose, blood cholesterol, urea and glycosylated haemoglobin and among its fractions, the ethyl acetate fraction was most effective in the reduction of blood glucose level at fasting condition and random conditions in both males and female mice and this amount of blood glucose was near to the amount of blood glucose reduced by Glucophage. The most effective plant i.e. Rhazya stricta leaves and particularly its ethyl acetate fraction can be used for the purification of most active phytochemical against hyperglycaemia.

\section{AUTHORS' CONTRIBUTION}

AA performed all experimental work for the evaluation of antidiabetic activity. MJA and MSA are members of supervisory committee. RQ collected and identified plant samples and given them voucher number. SIS supervised and provided all financial support during experimental work on mice. HG prepared and arranged all solutions for all lab work. MG supervised the financial support from Higher Education Commission, Islamabad, Pakistan under 5000 Indigenous Ph.D. Fellowship programme Phase VI.

\section{ACKNOWLEDGEMENT}

The authors highly acknowledge the financial support from Higher Education Commission, Islamabad, Pakistan under 5000 Indigenous Ph.D. Fellowship programme Phase VI PIN NO.106-1103-BM6-014 and the National Veterinary Laboratories, PARK Road, Islamabad for their technical support in the study.

\section{REFERENCES}

Ali, BH (1997) The effect on plasma glucose, insulin and glucagon levels of treatment of diabetic rats with the medicinal plant Rhazya stricta and with glibenclamide, alone and in combination. J. Pharmacy and Pharmacology 49(10): 1003- 7. PMID: 9364411

Al-Yahya, MA, Al-Meshal, IA, Mossa, JS, Al- Badr, AA and Tariq, AA (1990) Saudi Plants: A Phytochemical and Biochemical Approach. King Saud University Press Riyadh, Saudia Arabia.

Atta-Ur-Rahman, Atia-Tul-Wahab, Nawaz SA, Choudhary IM (2004). New cholinesterase inhibiting bisbenzylisoquinoline alkaloids from Cocculus pendulus. J. Chem Pharm Bull (Tokyo).;52(7):802-6. [DOI]

Burke, JP, Williams, K, Narayan, KMV, Leibson, C, Haffner, SM and Stern MP (2003) A population perspective on diabetes preventation: Whom should we target for preventing weight gain? J. Diabetes Care. 26: 19962004. [DOI]

Daisy, P. and Eliza, J. (2007) Hypoglycemic property of polyherbal formulation in streptozotocin induced diabetic rats. J. Biochemistry Cell. Arch. 7: 135-140.

Gonzalez, M, Zarzuelo, A, Gamez, MJ, Utrilla, MP, Jimenez, J and Osuna, I (1992) Hypoglycaemic activity of olive leaf. J. Plantation and Medicine 58: 513- 515. [DOI]

Grover, JK, Vats, V, Rathi, SS and Dawar, R (2001) Traditional Indian antidiabetic plants attenuate renal damage in streptozotocin induced diabetic mice. J. Ethanopharmacology 76: 233- 238. [DOI]

Jaya, PP (2013) Herbal medicine for diabetes mellitus: a review. International J. Phytopharmacy 3 (1). [DOI]

Muhammad NA, Shahnaz AR, Muhammad, Mahmood-Ul-Hassan, Nureen R and Munawar I (2013) Phytochemical Constituents of Weeds: Baseline Study In Mixed Crop Zone Agroecosystem. Pak. J. Weed Sci. Res., 19(2): 231-238, 2013

Noor, A, Gunasekaran S, Manickam AS and Vijayalakshmi MA (2008) Antidiabetic activity of Aloe vera and histology of organs in streptozotocin induced diabetic rats. J. Current Science 94: 1070- 1076. ISSN 0011- 3891.

Upadhaya, VP and Pandey K (1984) Ayurvedic approach to diabetes mellitus and its management by indigenous resources. Diabetes Mellitus in developing countries. Journal of Bajaj JS. (Ed) New Delhi.

World Health Organization (1980) Diabetes mellitus. 2nd Rep, Geneva WHO Technical report series, 646. ISBN 9241206462.

Yamauchi T, Kamon J, Ito Y, Tsuchida A, Yokomizo T, Kita S, et al. (2003) Cloning of adiponectin receptors that mediate antidiabetic metabolic effects. Nature. 12; 423(6941):762-9. PMID: 12802337 